\title{
INDUSTRIAL SYMBIOSIS IN A CIRCULAR ECONOMY: TOWARDS FIRMS' SUSTAINABLE COMPETITIVE ADVANTAGE
}

\author{
João Lopes ${ }^{1}$, Luís Farinha \\ ${ }^{1}$ NECE - Research Centre in Business Science \\ University of Beira Interior, Estrada do Sineiro, s/n., 6200-209 Covilhã Portugal \\ ${ }^{2}$ Polytechnic Institute of Castelo Branco \& CIPEC - Research Center in Heritage, Education and Culture, and NECE - \\ Research Centre in Business Sciences, Largo do Município, Idanha a Nova, 6060-163 Portugal \\ joao.lopes.1987@hotmail.com or joao.nuno.morais.lopes@ubi.pt, \\ luis.farinha@ipcb.pt
}

\begin{abstract}
The main objective of this article is to provide a comprehensive view of academic studies that address simultaneously the circular economy and industrial symbiosis, based on bibliometric data for the years 1900 to 2018. Data are collected in Web of Science using the VOSviewer software. Bibliometric indicators, network citation, cluster analysis, and density view analysis are used. From our findings we highlight four clusters in the research, which help to contextualize the literature review: (a) circular economy: approaches and tools; (b) industrial symbiosis Dynamics; (c) circular economy: strategies and performance; (d) the efficiency of resources in symbiosis industry. This study also establishes perspectives for future lines of research and, correspondingly, seeks to provide a theoretical basis that can serve as a starting point for future studies.
\end{abstract}

Keywords: Industrial Symbiosis, Circular Economy, Sustainability, Competitive Advantage.

\section{Introduction}

In recent years, the concept of the Circular Economy (CE) has gained the attention of institutions, scholars and companies (Griffiths \& Cayzer, 2016; Merli, Preziosi, \& Acampora, 2018). The era of low-cost resources is over, natural resources are increasingly limited, which has led to the growing demand for new business attitudes that can help organizations and society move towards sustainable development (Hill, 2014; McDowall et al., 2017).

The growing demand requires a shift from a linear design to a circular design, which can be represented by the notion of CE. At present, the CE has been adopted as a basic principle in the emergence of new policies from many countries that have approached their implementation in different ways. The CE concept consists of an economic system that replaces the idea of "end of life" with the practice of reducing or reusing, recycling and recovering materials used in production, distribution and consumption processes. Thus, the concept of CE is based on three principles: 1) preserving and improving natural capital, controlling finite stocks and balancing flows of renewable resources; 2) to optimize the yield of resources, circulating products, components and materials of the highest utility in technical and biological cycles; 3 ) to promote the effectiveness of the system by revealing and projecting negative externalities (Abreu \& Ceglia,
2018; George, Lin, \& Chen, 2015; Griffiths \& Cayzer, 2016; Kirchherr, Reike, \& Hekkert, 2017).

The CE is often contextualized as a way of extending the values of resources, especially through recycling and industrial symbiosis (IS). The term of IS is understood as an industry that traditionally works in isolation yet collaborates in a network to have a competitive advantage that involves the physical exchange of materials, energy, water and by-products. The key to IS success is the collaboration and synergistic creation possibilities resulting from geographic proximity. IS relates to the flows and transformations of materials and energy that are generated by economic actors within a geographically connected system. Several countries, companies, NGOs (non-governmental organizations) and government agencies have sought to make these flows and transformations more sustainable (Boons, Spekkink, \& Mouzakitis, 2011; Chertow, 2007).

As gap's found in the literature it was verified that it is important to evaluate the diffusion of IS concepts and social routines, as well as changes in institutional capacity in the regional industrial systems (Boons et al., 2011). The transition from a linear economy to a circular economy should occur through a shift in regional policies to create a partnership between the business community, policymakers and institutions, which has not been established (Saavedra, Iritani, Pavan, \& Ometto, 2018). 
There is a need to investigate how to encourage business participation in more IS partnerships (Patricio, Axelsson, Biome, \& Rosado, 2018).

No systematic reviews of literature and bibliometrics were found in the Web of Science database to study the impact of EC and IS on industrial sustainability. Thus, the objective of this study is to provide a comprehensive view of academic studies that simultaneously address CE and IS and industrial sustainability. The theme under study remains relatively recent, and for the first time the combination of the terms of the circular economy, industrial symbiosis and sustainability appeared for the first time in the year 2008. The present study contributes to analysing the theoretical contribution of the importance of CE and IS in industrial sustainability. To perform this bibliometric review, we resorted to the Web of Science database and applied some filters to exclude publications that are not relevant to our study.

In this context, we will verify the trends in this field, as well as the identification of the most prominent sub-themes. We will seek to open new horizons for future publications, as well as reveal the most relevant authors and journals on this topic. Identifying the authors who produced most of the articles clearly responds to the important need to understand how, when, and where interest in this topic arose. This approach also points to the studies that served as the basis for the construction of research on the subject under study.

This review addresses the concepts of "circular economy", "industrial symbiosis" and "sustainability", in addition to any others found in the context of this review.

The structure of this article is as follows: following this introduction, we move onto setting out the literature review. Thirdly, we detail the methodology applied before analyzing and discussing the results returned. Finally, we provide our conclusions while identifying limitations to this study alongside future lines of research.

\section{State-Of-The-Art}

The scientific literature has already studied CE under various perspectives. The main research flows that deal with this topic are: industrial ecology, environmental, political and social science, and literature on product design practices (Urbinati, Chiaroni, \& Chiesa, 2017).

Interest in studies on the EC has been particularly strong since countries such as China, the United Kingdom, and the European Union have begun to legislate on the subject. The publications aimed at highlighting the definition of CE, their fields of action, the role of IS and related environmental certifications (Boons et al., 2011; Prieto-Sandoval, Jaca, \& Ormazabal, 2018; Prieto-Sandoval, Ormazabal, Jaca, \& Viles, 2018).
For the present study, CE is considered as an economic system that represents a paradigm shift in the way human society is interrelated with nature in order to prevent resource depletion, close energy and material ties, and facilitate sustainable development through its implementation at the micro (business and consumer) levels, meso (economic agents integrated in symbiosis) and macro (cities, regions and governments) (Prieto-Sandoval et al., 2018). The aim of the CE is to replace existing open production systems based on a linear consumption model, where raw materials are extracted, processed into finished products and become waste after being consumed (Geng, Zhu, Doberstein, \& Fujita, 2009; McDonough \& Braungart, 2010; Xue et al., 2010).

This new industrial paradigm has encouraged people to behave more sustainably and has awakened for policymakers the need to develop CEoriented environmental and management policies. Thus, new regulations have emerged that incorporate the principles of sustainability (Besio \& Pronzini, 2014; Murray, Skene, \& Haynes, 2017; Schneider, 2015). It is in this context that the IS emerges.

The IS involves flows, as well as the cycle of materials and energy, synergistic interactions between companies, through which waste is converted into inputs. By replacing inputs with waste, companies can increase their production efficiency, which allows them to reduce the costs of waste disposal and the costs of acquiring inputs. The material provision, resource reuse and financial advantage were associated with the perception of the companies about the CE. These opportunities arise through the integration of companies and industry associations or clusters to develop IS and close their material cycles (Ayres \& Ayres, 2002; Fraccascia \& Yazan, 2018; Ormazabal, PrietoSandoval, Puga-Leal, \& Jaca, 2018).

In this context, the objective of this bibliometric review is to provide a comprehensive view of academic studies that simultaneously address CE and IS and their sustainability, to identify gaps in the literature and provide possible directions for future research lines in the subject. Thus, the study addresses the following research question: How does the academic world address the study of CE and IS? From this general question, more specific questions arise: Who are the protagonists, considering the source of the publications as well as the authors? Which methodologies and types of research are most used? What is the geographic focus of literature? What are the streams of future research lines?

The bibliometric review presented in the next sections of this study aims to answer the questions indicated above. This way we will analyze a significant part of the academic work in the subject under study. In relation to previous reviews 
produced by other scholars, it contains several novelties that provide added value to better understand the subject under study. Firstly, it explores sustainability, CE and IS with a systematic approach to provide an exhaustive and comprehensive analysis of the phenomenon with rigorous and reproducible research criteria. Secondly, it does not reduce the scope of the study to a specific focus, but it attempts to capture and relate all topics and research approaches related to articles that address sustainability, CE and IS simultaneous. The structural dimensions and associated analytical categories were elaborated to capture the largest number of sustainability, CE and IS issues. Finally, in relation to other studies, the main objective is to better understand how academics approach sustainability, CE and IS, highlighting trends and gaps, which will serve as the basis for future research on the subject.

\section{Methodology}

Bibliometrics is the application of quantitative tools to the study of scientific communications and has been applied in various forms for more than a century. The bibliometric analysis allows making an evaluation of the scientific quality and influence of the different publications and sources (Bouyssou \& Marchant, 2011; Cooper \& Valentine, 2008; Leydesdorff, 2005; Pritchard, 1969).

With the bibliometric analysis, it is possible to filter useful information for the academics and professionals who study and want to deepen their knowledge within a particular field of research (Duque Oliva, Cervera Taulet, \& Rodríguez Romero, 2006).

In order to prepare a bibliometric analysis, it is necessary to follow six steps: 1) define the field under study, 2) choose the database, 3) adjust the search criteria, 4) compile the categories of bibliographic information, 5) code the recovered material and, finally, 6) analyze the information (Albort-Morant \& Ribeiro-Soriano, 2016).

Among the various bibliographic databases, we use the Web of Science (WOS), more specifically the Web of Science Core Collection, published by Thomson Reuters. The present bibliometric study is an analysis of the current state of the art of the most relevant research works in the field under analysis.

The data found in the WOS are considered the central source of information for an extensive bibliometric exploration within the social sciences. The data covered in the WOS has a high level of acceptance in the academic community and is therefore essential for our analysis. The WOS is still the only bibliographic database that normalizes the cited references for each article record throughout the collection, allows us to make bibliographic couplings. With other databases, as a rule, it is not possible to make bibliographic (Franceschini, Faria, \& Jurowetzki, 2016; Liu, Yin, Liu, \& Dunford, 2015).

The key words "industrial symbiosis", "circular economy" and sustainability ("Sustainab *") were used to match the most relevant publications in the field under study. The search was performed on $1 / 18 / 2019$. It was selected as a timeline from 1900 to 2018. The review was limited to articles, omitted books, book chapters, and other unvalidated publications since articles can be considered validated knowledge having a greater impact on the ground (Keupp, Palmié, \& Gassmann, 2012). After this selection has been filtered for review 59 articles.

\section{Analysis and Discussion of the Results}

The scope of this analysis covers all articles in the field of study, languages and countries available because the purpose of this research is to provide a comprehensive view of academic studies that simultaneously address CE and IS and their sustainability.

\subsection{Number of publications per year}

The origin of the concept of EC is not consensual and there is no clear evidence of a single origin or originator of the concept of EC. However, a careful analysis shows that it was in the second half of the 1960s that the concept emerged. Some scholars consider that the British economist Kenneth Boulding is the father of the idea with the publication "The Economics of Coming Spaceship Earth" published in 1966. The author addresses the "closed economy of the future" or "spaceman economy" comparing a spacecraft with the planet Earth. Thus, he states that the planet Earth is finite and has no unlimited reservoirs of material resources. It concludes that there are limits to the extraction of material resources, as well as to the absorption of pollution. In this context, man must find his place in a cyclical ecological system. This cyclical ecological system has to be able to continually renew its material resources, although it cannot do without receiving external energy inputs (Boulding, 1966).

Despite the above mentioned, other authors are referred to as contributing in the first phase to the development of the EC concept such as the American professor John Lyle, his student William McDonough, the German chemist Michael Braungart, and architect and economist Walter Stahel (Abreu \& Ceglia, 2018).

The principles of the EC concept include 3Rs (reduce, reuse, recycle) and 6Rs (reuse, recycle, redesign, remanufacturing, reduce, recover). The EC began operating in the 1980s and 1990s, with the Netherlands and Germany pioneering the implementation of waste prevention and recovery 
policies (Jawahir \& Bradley, 2016; Wu, Shi, Xia, \& Zhu, 2014).

The concept of CE is intertwined with several other concepts that have emerged previously, such as industrial symbiosis. Sometimes the terms industrial symbiosis, eco-industrial network, and eco-industrial park are used in the literature synonymously. It is important, however, to distinguish between these terms because the scale and scope of the actors' objectives and practice are different, as well as the possible synergies that may exist for each initiative.

A critical point is that the spatial relationship, that is, the distance between the industries, influences the flows of energy and materials between the different entities (Chertow \& Ehrenfeld, 2012; Chertow, 2007; Peck, Kandachar, \&
Tempelman, 2015; Van Beers, Bossilkov, Corder, \& Van Berkel, 2007; Winans, Kendall, \& Deng, 2017).

The eco-industrial park includes the exchange of water, energy, information and/or materials to minimize the use of energy and raw materials, reduce waste and thus build sustainable economic, ecological and social relations.

Eco-industrial networks or industrial symbiosis networks have also evolved with the same idea as eco-industrial park parks, but cover a wider geographical area within a region, province, or country (Boix, Montastruc, Azzaro-Pantel, \& Domenech, 2015; Winans et al., 2017).

This being the context of our study, we were able to verify the evolution of the publication of the panoply of previously selected articles (59 articles) (figure 1).

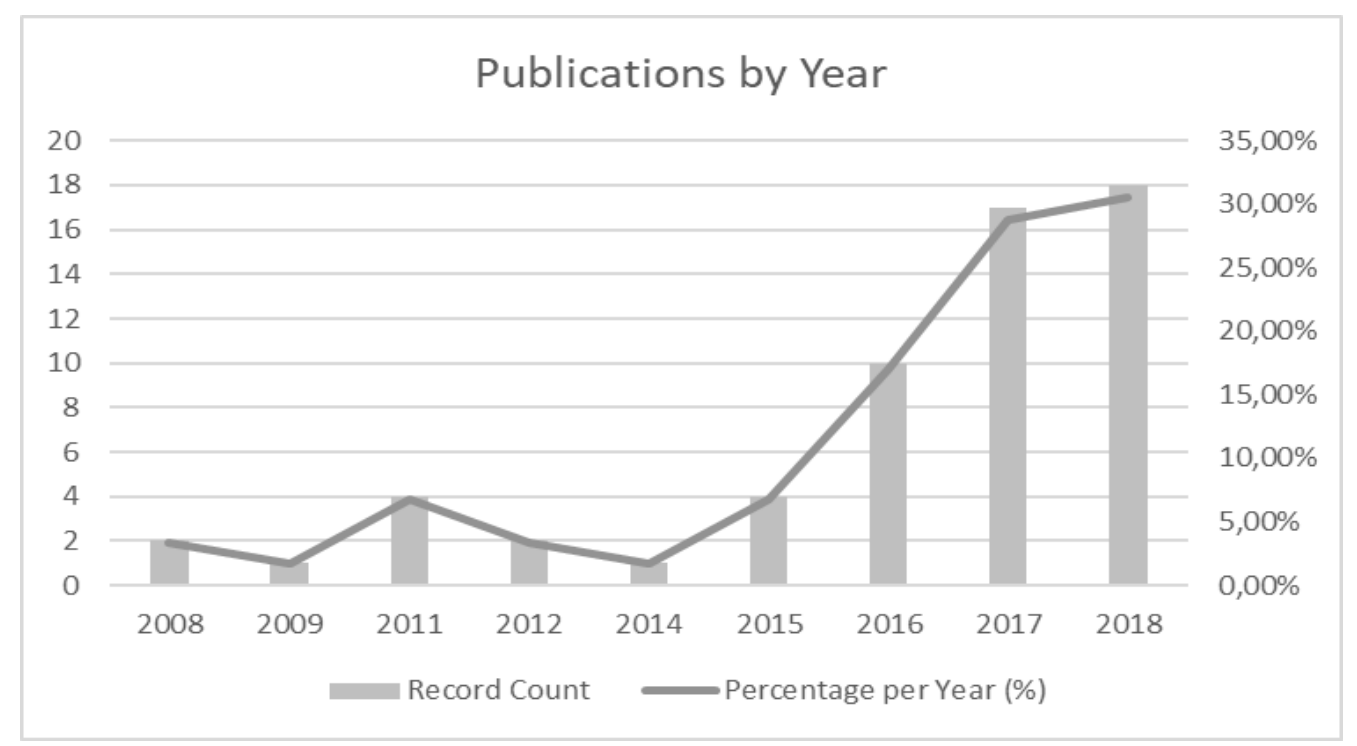

Figure 1 - Publications by year

As can be seen in Figure 1, the simultaneous studies of EC and IS and their sustainability started in 2008 with the article "Case study of industrial symbiosis: Nanning Sugar Co., Ltd. in China" by the authors Yang and Feng (2008). Analyzing figure 1 we can distinguish 2 distinct periods/phases in the evolution of the publications of the articles. The first period covers the years between 2008 and 2015 and a second period from 2016 to 2018 .

The first period includes 14 articles, corresponding to $23.73 \%$ of the articles under analysis. Most of the studies are conceptual or case studies where models are proposed to implement and develop CE and IS. The factors, processes, dynamics and policies resulting from the CE and IS are also verified, always aiming at the sustainability of the regions and their companies (Boons et al., 2011; Geng \& Doberstein, 2008; Geng, Fu, Sarkis, \& Xue, 2012; Gregson, Crang, Fuller, \& Holmes, 2015).
The interest of scholars accentuated in the second period. This period includes 45 articles which correspond to $76.27 \%$ of the articles under analysis. In 2016 it is verified that 10 articles were published, however in 2018 almost twice the published articles (18). The perspective is that the number of articles published per year, in the subject under analysis, will grow. In this period, the articles are in general case studies.

The articles cover, in general, the transition from a linear economy to a circular economy, product design and business model strategies for companies, problems in their implementation, and forms of cooperation to create synergies between companies (Alvarez \& Ruiz-Puente, 2017; Bocken, de Pauw, Bakker, \& van der Grinten, 2016; Herczeg, Akkerman, \& Hauschild, 2018; Kuznetsova, Zio, \& Farel, 2016; Sposato, Preka, Cappellaro, \& Cutaia, 2017; Urbinati et al., 2017). 


\subsection{Authors and Countries with the greatest productivity}

Many authors from a wide variety of backgrounds have conducted research on the subject under study and published their findings in scientific journals indexed in the Web of Science of Thomson
Reuters. In this section, we show the 20 most striking authors in the field of study (table 1).

To filter the 20 most striking authors was defined as a minimum of 50 citations. However, in the 59 articles, there are 183 authors.

Tabel 1 - Most important authors in the literature

\begin{tabular}{|l|l|r|r|l|l|r|r|}
\hline Rank & Author & Documents & Citations & Rank & Author & Documents & Citations \\
\hline 1 & Geng, Y & 8 & 354 & 11 & Bakker, C & 1 & 94 \\
\hline 2 & Fu, J & 150 & 12 & Bocken, NMP & 1 & 94 \\
\hline 3 & Sarkis, J & 1 & 150 & 13 & De Pauw, I & 1 & 94 \\
\hline 4 & Xue, B & 1 & 150 & 14 & Van Der & 1 & 94 \\
\hline 5 & Doberstein, B & 1 & 134 & 15 & Crang, M & 1 & 62 \\
\hline 6 & Mathews, Ja & 2 & 126 & 16 & Fuller, S & 1 & 62 \\
\hline 7 & Tan, H & 2 & 126 & 17 & Gregson, N & 1 & 62 \\
\hline 8 & Boons, F & 2 & 115 & 18 & Holmes, H & 1 & 62 \\
\hline 9 & Mouzakitis, Y & 1 & 102 & 19 & Feng, N & 1 & 54 \\
\hline 10 & Spekkink, W & 1 & 102 & 20 & Yang, S & 1 & 54 \\
\hline
\end{tabular}

As can be seen in table 1 the most prolific author on the subject is Geng, $\mathrm{Y}$ with 354 citations in 8 published articles. The author Geng, Y has 257 articles published in WOS having developed his research in several fields as for example in environmental sciences, engineering environmental, green sustainable science technology, energy fuels, and environmental studies.

For countries that contribute most to the scientific productivity in the subject in question, what stands out most is China with 15 articles and 492 citations. The articles that stand out with the most quotations are: 150 citations - authors' "Towards a national circular economy indicator system in China: an evaluation and critical analysis" Geng et al. (2012); 134 citations - "Developing the circular economy in China: Challenges and opportunities for achieving 'leapfrog development'" by authors Geng and Doberstein (2008); 54 citations - "Case study of industrial symbiosis: Nanning Sugar Co., Ltd. in China" by the authors Yang and Feng (2008).

Second is the Netherlands with 10 articles published and 341 citations. Of the 10 articles, the following stand out: 102 citations - the authors of the paper "The dynamics of industrial symbiosis: a proposal for a conceptual framework based on a comprehensive literature review" Boons et al.
(2011); 94 citations - authors' "model design and business strategies for a circular economy" Bocken et al. (2016); 47 citations - "Process analysis of ecoindustrial park development - the case of Tianjin, China" Yu, de Jong, and Dijkema (2014).

In third place, England also appears with 10 articles, but with 244 citations (less 97 citations than the Netherlands). Of the 10 articles the following stand out: 94 citations - "Product design and business modelling strategies for a circular economy" by the authors Bocken et al. (2016) (this is second with more relevance also in the Netherlands); 62 Citations - "Interrogating the Circular Economy: The Moral Economy of Resource Recovery in the EU" by the authors Gregson et al. (2015); 48 citations - authors' "circular economy design considerations for research and process development in the chemical sciences" Clark, Farmer, Herrero-Davila, and Sherwood (2016).

\subsection{Most productive journals}

In the 59 articles under analysis, 23 journals were identified. Table 2 shows the most productive journals in the field under study. 
Tabel 2 - Journals with a greater number of studies

\begin{tabular}{|c|c|c|c|c|c|c|c|}
\hline Rank & Journal & $\begin{array}{l}\text { Number of } \\
\text { publication } \\
\text { S }\end{array}$ & Citations & Rank & Journal & $\begin{array}{c}\text { Number of } \\
\text { publication } \\
\text { s }\end{array}$ & Citations \\
\hline 1 & $\begin{array}{l}\text { Journal of Cleaner } \\
\text { Production }\end{array}$ & 19 & 463 & 13 & $\begin{array}{l}\text { Asian Business \& } \\
\text { Management }\end{array}$ & 1 & 14 \\
\hline 2 & $\begin{array}{l}\text { Resources } \\
\text { Conservation and } \\
\text { Recycling }\end{array}$ & 7 & 108 & 14 & Energy Policy & 1 & 14 \\
\hline 3 & $\begin{array}{l}\text { Journal of Industrial } \\
\text { Ecology }\end{array}$ & 6 & 189 & 15 & $\begin{array}{l}\text { Ecological } \\
\text { Economics }\end{array}$ & 1 & 6 \\
\hline 4 & Sustainability & 5 & 16 & 16 & $\begin{array}{c}\text { Environmental } \\
\text { Innovation and } \\
\text { Societal Transitions }\end{array}$ & 1 & 6 \\
\hline 5 & $\begin{array}{l}\text { Waste and Biomass } \\
\text { Valorization }\end{array}$ & 2 & 12 & 17 & $\begin{array}{c}\text { Journal of } \\
\text { Environmental } \\
\text { Management }\end{array}$ & 1 & 5 \\
\hline 6 & Sustainability Science & 2 & 10 & 18 & $\begin{array}{c}\text { Environmental } \\
\text { Engineering and } \\
\text { Management } \\
\text { Journal }\end{array}$ & 1 & 2 \\
\hline 7 & $\begin{array}{l}\text { Scientific Papers- } \\
\text { Series Management } \\
\text { Economic } \\
\text { Engineering in } \\
\text { Agriculture and Rural } \\
\text { Development }\end{array}$ & 2 & 0 & 19 & $\begin{array}{l}\text { Production Planning } \\
\quad \& \text { Control }\end{array}$ & 1 & 1 \\
\hline 8 & $\begin{array}{l}\text { International Journal } \\
\text { of Sustainable } \\
\text { Development and } \\
\text { World Ecology }\end{array}$ & 1 & 134 & 20 & $\begin{array}{l}\text { Revista Virtual de } \\
\text { Quimica }\end{array}$ & 1 & 1 \\
\hline 9 & $\begin{array}{l}\text { Journal of Industrial } \\
\text { and Production } \\
\text { Engineering }\end{array}$ & 1 & 94 & 21 & $\begin{array}{l}\text { Archives of Foundry } \\
\text { Engineering }\end{array}$ & 1 & 0 \\
\hline 10 & Economy and Society & 1 & 62 & 22 & $\begin{array}{c}\text { Business Strategy } \\
\text { and the } \\
\text { Environment }\end{array}$ & 1 & 0 \\
\hline 11 & Green Chemistry & 1 & 48 & 23 & $\begin{array}{l}\text { Open House } \\
\text { International }\end{array}$ & 1 & 0 \\
\hline 12 & $\begin{array}{l}\text { Sustainable } \\
\text { Production and } \\
\text { Consumption }\end{array}$ & 1 & 15 & & - & - & - \\
\hline
\end{tabular}

As can be seen in table 2, four journals stand out. The Journal of Cleaner Production published $32.20 \%$ of the articles under review, 19 publications that have 463 citations together. Second is "Resources Conservation and Recycling" with 7 publications and 108 citations.

This journal represents $11.86 \%$ of the articles under analysis. The third is the "Journal of Industrial Ecology" with 6 publications and 189 citations. The fourth magazine that publishes the most is the magazine "Sustainability" with 5 publications and 16 citations. This magazine represents $10.17 \%$ of the articles under analysis.

The remaining journals, in the articles under analysis, represent less than $10 \%$ each.
The research areas of research publications on the subject are environmental sciences (46 articles), green sustainable science technology (35 articles), engineering environmental (32 articles), and environmental studies (10 articles). It should be noted that each article, as a rule, has more than one area of research identified.

\subsection{Cluster analysis and future lines of research}

The VosViewer software detailed the network of references of the 59 articles and identified the clusters of more relevant studies on the subject. Each color identifies a cluster (figure 2). 


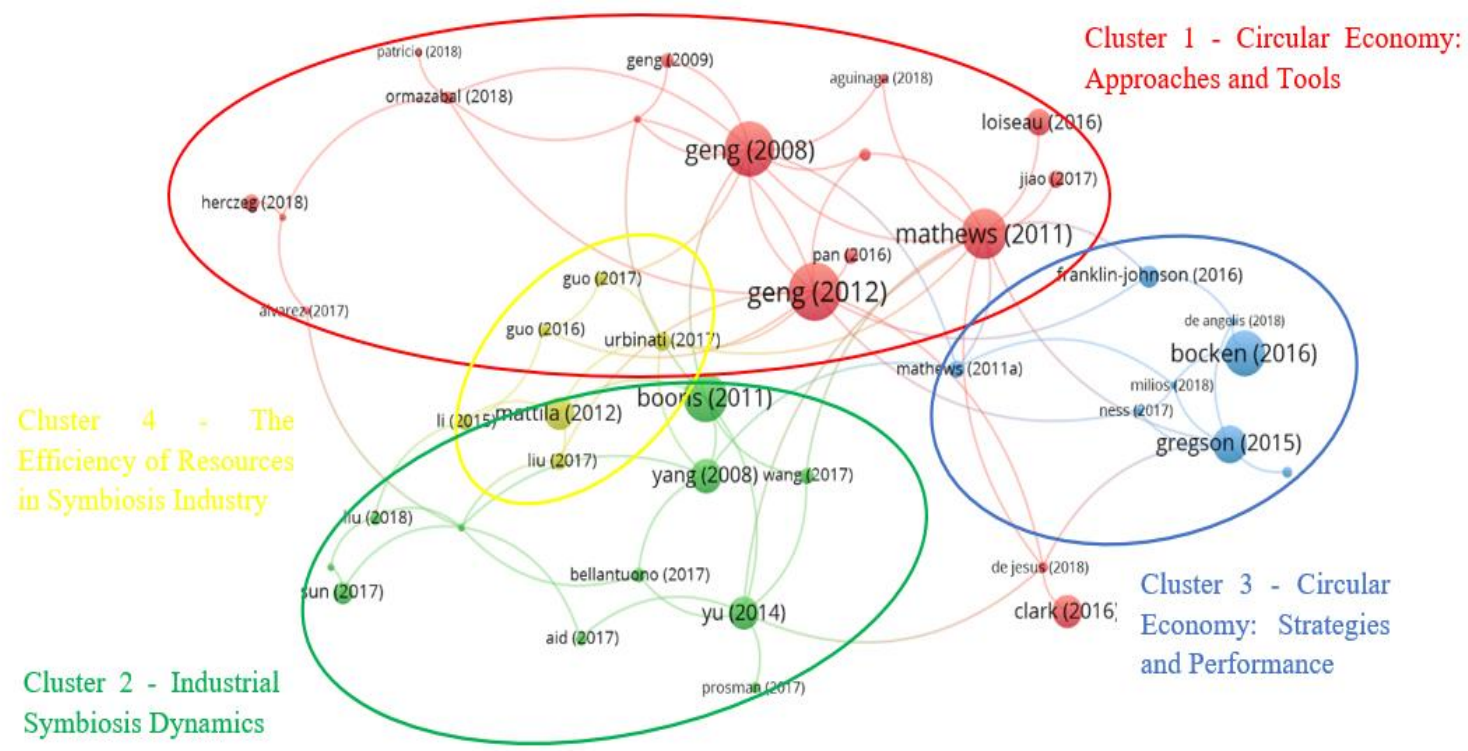

Figure 2 - Network of references and clusters

As can be seen in Figure 2, 4 clusters were formed. These 4 clusters are composed of 42 articles. VosViewer excluded 17 articles because they did not form any cluster (table 3). The cluster 1 (17 articles) was called "circular economy: approaches and tools", cluster 2 (11 articles) of "industrial symbiosis dynamics", cluster 3 (8 articles) and cluster 4 (6 articles) of "the efficiency of resources in symbiosis industry".

\begin{tabular}{|c|c|c|c|c|}
\hline $\begin{array}{c}\text { Cluster 1 - } \\
\text { Circular } \\
\text { Economy: } \\
\text { Approaches and } \\
\text { Tools } \\
\end{array}$ & $\begin{array}{l}\text { Cluster 2 - } \\
\text { Industrial } \\
\text { Symbiosis } \\
\text { Dynamics }\end{array}$ & $\begin{array}{c}\text { Cluster } 3 \text { - } \\
\text { Circular } \\
\text { Economy: } \\
\text { Strategies and } \\
\text { Performance }\end{array}$ & $\begin{array}{l}\text { Cluster } 4 \text { - The } \\
\text { Efficiency of } \\
\text { Resources in } \\
\text { Symbiosis } \\
\text { Industry }\end{array}$ & Excluded Articles \\
\hline $\begin{array}{c}\text { Aguiñaga, } \\
\text { Henriques, Scheel, } \\
\text { and Scheel (2018) }\end{array}$ & $\begin{array}{l}\text { Afshari, Farel, and } \\
\text { Peng (2018) }\end{array}$ & $\begin{array}{l}\text { Bocken et al. } \\
\text { (2016) }\end{array}$ & $\begin{array}{c}\text { Guo, Geng, Sterr, } \\
\text { Dong, and Liu } \\
\text { (2016) }\end{array}$ & $\begin{array}{l}\text { Hara, Yabar, Uwasu, } \\
\text { and Zhang (2011) }\end{array}$ \\
\hline $\begin{array}{l}\text { Álvarez and Ruiz- } \\
\text { Puente (2017) }\end{array}$ & $\begin{array}{c}\text { Aid, Eklund, } \\
\text { Anderberg, and } \\
\text { Baas (2017) }\end{array}$ & $\begin{array}{l}\text { Angelis, Howard, } \\
\text { and Miemczyk } \\
\text { (2018) }\end{array}$ & $\begin{array}{c}\text { Guo, Geng, Sterr, } \\
\text { Zhu, and Liu (2017) }\end{array}$ & $\begin{array}{c}\text { Strazza, Magrassi, } \\
\text { Gallo, and Del Borghi } \\
(2015)\end{array}$ \\
\hline Clark et al. (2016) & $\begin{array}{c}\text { Bellantuono, } \\
\text { Carbonara, and } \\
\text { Pontrandolfo } \\
\text { (2017) }\end{array}$ & $\begin{array}{l}\text { Franklin-Johnson, } \\
\text { Figge, and } \\
\text { Canning (2016) }\end{array}$ & $\begin{array}{l}\text { Li, Dong, and Ren } \\
\text { (2015) }\end{array}$ & $\begin{array}{c}\text { Wang, Xu, and Zhu } \\
\text { (2015) }\end{array}$ \\
\hline $\begin{array}{c}\text { Jesus and } \\
\text { Mendonça (2018) }\end{array}$ & Boons et al. (2011) & $\begin{array}{l}\text { Crang, Fuller, and } \\
\text { Holmes (2015) }\end{array}$ & Liu et al. (2017) & $\begin{array}{c}\text { Manara and } \\
\text { Zabaniotou (2016) }\end{array}$ \\
\hline $\begin{array}{c}\text { Geng and } \\
\text { Doberstein (2008) }\end{array}$ & $\begin{array}{l}\text { Fraccascia and } \\
\text { Yazan (2018) }\end{array}$ & $\begin{array}{l}\text { Mathews, Tang, } \\
\text { and Tan (2011) }\end{array}$ & $\begin{array}{l}\text { Mattila, Lehtoranta, } \\
\text { Sokka, Melanen, } \\
\text { and Nissinen } \\
\text { (2012) }\end{array}$ & $\begin{array}{l}\text { Kuznetsova et al. } \\
\text { (2016) }\end{array}$ \\
\hline $\begin{array}{l}\text { Geng, Mitchell, and } \\
\text { Zhu (2009) }\end{array}$ & $\begin{array}{l}\text { Liu, Adams, Cote, } \\
\text { Geng, and Li } \\
\text { (2018) }\end{array}$ & Milios (2018) & $\begin{array}{l}\text { Urbinati et al. } \\
\text { (2017) }\end{array}$ & $\begin{array}{c}\text { Renzulli, Notarnicola, } \\
\text { Tassielli, Arcese, and } \\
\text { Di Capua (2016) }\end{array}$ \\
\hline Geng et al. (2012) & $\begin{array}{c}\text { Prosman, } \\
\text { Wæhrens, and } \\
\text { Liotta (2017) }\end{array}$ & $\begin{array}{l}\text { Ness and Xing } \\
\quad(2017)\end{array}$ & - & Du (2016) \\
\hline $\begin{array}{l}\text { Herczeg et al. } \\
\quad \text { (2018) }\end{array}$ & Sun et al. (2017) & $\begin{array}{c}\text { Prendeville, } \\
\text { Cherim, and } \\
\text { Bocken (2018) }\end{array}$ & - & $\begin{array}{l}\text { Frone and Frone } \\
\qquad(2017 a)\end{array}$ \\
\hline
\end{tabular}




\begin{tabular}{|c|c|c|c|c|}
\hline $\begin{array}{c}\text { Jiao and Boons } \\
\text { (2017) }\end{array}$ & $\begin{array}{l}\text { Wang, Deutz, and } \\
\text { Chen (2017) }\end{array}$ & - & - & $\begin{array}{c}\text { Frone and Frone } \\
(2017 \mathrm{~b})\end{array}$ \\
\hline $\begin{array}{c}\text { Loiseau et al. } \\
\text { (2016) }\end{array}$ & $\begin{array}{l}\text { Yang and Feng } \\
(2008)\end{array}$ & - & - & $\begin{array}{l}\text { Ferreira, Silva, and } \\
\text { Ferreira (2017) }\end{array}$ \\
\hline $\begin{array}{c}\text { Mathews and Tan } \\
\text { (2011) }\end{array}$ & Yu et al. (2014) & & - & $\begin{array}{l}\text { Ceglia, Abreu, and } \\
\text { Silva Filho (2017) }\end{array}$ \\
\hline $\begin{array}{l}\text { Mulrow, Derrible, } \\
\text { Ashton, and } \\
\text { Chopra (2017) }\end{array}$ & - & - & - & Sposato et al. (2017) \\
\hline $\begin{array}{c}\text { Ormazabal et al. } \\
\text { (2018) }\end{array}$ & - & - & - & $\begin{array}{c}\text { Sappinen, Orkas, and } \\
\text { Kronqvist (2018) }\end{array}$ \\
\hline Pan et al. (2016) & - & - & - & $\begin{array}{c}\text { Nasiri, Rantala, } \\
\text { Saunila, Ukko, and } \\
\text { Rantanen (2018) }\end{array}$ \\
\hline $\begin{array}{c}\text { Patricio, Axelsson, } \\
\text { Blomé, and Rosado } \\
\text { (2018) }\end{array}$ & - & - & - & $\begin{array}{l}\text { Velenturf, Purnell, } \\
\text { Tregent, Ferguson, } \\
\text { and Holmes (2018) }\end{array}$ \\
\hline $\begin{array}{c}\text { Pigosso, } \\
\text { Schmiegelow, and } \\
\text { Andersen (2018) }\end{array}$ & - & - & - & $\begin{array}{l}\text { Mohammed, Biswas, } \\
\text { Yao, and Tade (2018) }\end{array}$ \\
\hline $\begin{array}{l}\text { Prieto-Sandoval, } \\
\text { Ormazabal, Jaca, } \\
\text { and Viles (2018) }\end{array}$ & - & - & - & Blomsma (2018) \\
\hline 17 Articles & 11 Articles & 8 Articles & 6 Articles & 17 Articles \\
\hline
\end{tabular}

The cluster 1 "circular economy: approaches and tools" has several articles that clarify theories, concepts, approaches and tools associated to the circular economy or green economy (Clark et al., 2016; Loiseau et al., 2016).

Overall, the green economy shows that different concepts and approaches are available and can be used to support the transition to sustainability. However, doubts were expressed about the ability of a green economy to support the transition to sustainability. This doubt is explained by the two different visions of sustainability that can be found in the two economic theories related to the green economy, that is, weak sustainability and strong sustainability (Loiseau et al., 2016).

In this context, most of the companies continue to operate under a linear model (Alvarez \& RuizPuente, 2017; Geng \& Doberstein, 2008). Companies must equip themselves with tools that facilitate their shift to the circular paradigm. The implementation of this new paradigm is seen as a way in which regions can overcome past environmental damage. These regions are usually characterized by having an industrialized economy.

Prieto-Sandoval et al. (2018), used the Delphi method to validate and define the key elements that facilitate the change of companies to the circular paradigm. They define three categories: fields of action of the circular economy, IS and environmental certifications. In this way, small and medium enterprises will be able to understand where they are and what they need to do to improve their performance.

The cluster 2 "industrial symbiosis dynamics" addresses the various dynamics that the IS has to have in order to change the paradigm of the companies to circulate to the detriment of the linear one. This cluster includes articles that help to understand the dynamics through which regional industrial systems alter their connectivity to reduce their ecological impact (Boons et al., 2011; Sun et al., 2017).

In this context, ecological impacts become prominent in national CE practices. The interlinked industrial and regional economic development and related environmental and ecological challenges have come to prominence in the (Afshari et al., 2018; Aid et al., 2017).

In order to achieve the expected results with the development of IS, it is important for regions to set up networks for this purpose, such as an ecoindustrial park. It is essential that regional networks develop knowledge to encourage local businesses to engage in IS (Ceglia et al., 2017; Wang et al., 2017). 
The cluster 3 "circular economy: strategies and performance" generally address business strategies and performance in the transition from a linear economy to a CE (Bocken et al., 2016; FranklinJohnson et al., 2016).

To transform the economy from linear to circular, the business model and design strategies will need to go hand in hand. Potentially, multiple business model strategies, approaches, methods and tools are needed to support change to an $\mathrm{CE}$, such as a synergistic combination of business model strategies (sufficiency and classical long life) and product design strategies ( for example, product design for durability and design for upgradability)(Bocken et al., 2016).

Policymakers have made efforts to understand the conceptual aspects of the $\mathrm{CE}$ and each has a unique point of view on its meaning, from a strategic ambition (actually a contemporary view of sustainability) to a niche concept included in the phenomenon of the intelligent city. It is still seen as a means to an end (a tool), but this end is not clear (Prendeville et al., 2018).

Regarding performance, there are techniques that evaluate the use of resources based on the value-related burden. However, the central point of the $\mathrm{CE}$ is to create value through the retention of materials. Thus, it is important to measure performance through the longevity indicator, which measures the contribution to material retention based on the amount of time a resource is kept in use. The measure is made up of three generic components: initial lifetime, lifetime reclaimed gain and lifetime recycled gain. The management of these three components can be used for decision making and performance evaluation in the CE (FranklinJohnson et al., 2016).

Articles that incorporate Cluster 4 "The Efficiency of Resources in Symbiosis Industry", in general, explore resource efficiency in the regions. The CE is the main national strategy to be developed by countries to achieve long-term sustainable development. IS is a practical approach to promote the CE to achieve environmental and economic benefits simultaneously (Guo et al., 2016; Guo et al., 2017; Li et al., 2015).

Regional governments have given increasing importance to the sustainability of the regions. Behaviors and lifestyles play a vital role in achieving sustainable development. In this context, IS has become a frequent discussion, with policymakers paying special attention to the issue to achieve efficient and effective implementation. The reasons are due to the rapid advance and growth urbanizations, the serious shortage of resources and the environmental contaminations that are becoming accentuated more and more in the regions. With the depletion of natural resources and the degradation of the environment, the concept of sustainability and economic transition solutions become increasingly important. The chemical industry is a key industry to promote IS because it has several materials and differentiating energy flows (Guo et al., 2016; Guo et al., 2017; Li et al., 2015).

The results of IS implementation have been positively highlighting a drastic reduction of resources, reduction of solid waste and mitigation of carbon dioxide emissions, as well as generating revenue for companies and local business opportunities. IS can bring significant environmental and economic benefits to practitioners through the exchange of by-products and knowledge sharing (Guo et al., 2016; Guo et al., 2017; Li et al., 2015).

At the socio-economic level, it is important to Introduce in the public knowledge the best practices related to the CE; Establish EC sites or information platform for public participation; Provide preferential policies to producers of green products; Optimize the industrial structure; Promote the development of the service industry; Promote the construction of infrastructure for urban water supply and drainage, heating, gas and treatment of garbage removal and other municipal utilities; Accelerate the construction of a series of sewage treatment; Control of air pollution and other environmental projects; Reform of the resource pricing mechanism (Guo et al., 2017; Li et al., 2015).

At the environmental level, it is important to Implement unified collection and treatment for waste in mining and industrial cluster; Development of clean energy strategies, improving the efficiency of industrial resources; Tax incentives should be created; Regulate hazardous waste management by accelerating the construction of urban waste disposal facilities; Promote cleaner production, energy-saving technology and product development in key industries; Promote the reduction, reuse and recycling of bulky waste; Establish compensation mechanisms for resource exploitation (Li et al., 2015; Liu et al., 2017).

With the implementation of CE and IS the environmental and economic benefits are evident. There is clear evidence that the environmental level includes both the reduction of the consumption of resources of the units of inputs and the reduction of the emissions of residues of the production units. In relation to the economic benefits, there is a clear saving of cost of raw material purchase, saving of residues and revenue from sales of waste (Guo et al., 2016).

In order to further deepen our research, we will then check which subtopics are the most studied in the subject under study and those that still need to be investigated in the future. For this we will use the analysis "density view" of VosViewer. This analysis is particularly useful for getting an overview of the overall structure of a map and drawing attention to the most important areas on a map (Eck \& Waltman, 2009). To understand the results of the VosViewer 
analysis, we need to understand the meaning of the colors (figure 3). There are three colors exhibiting different levels of density. The green color indicates that the sub-theme is still under-exploited, therefore it exhibits a minimum level of density. The yellow color identifies an intermediate level for the identified sub-theme and, therefore, the average density. Finally, the red color highlights as this is a subtopic in which the researchers focused more, i.e. it is the maximum density level (Lopes, Ferreira, \& Farinha, 2018).

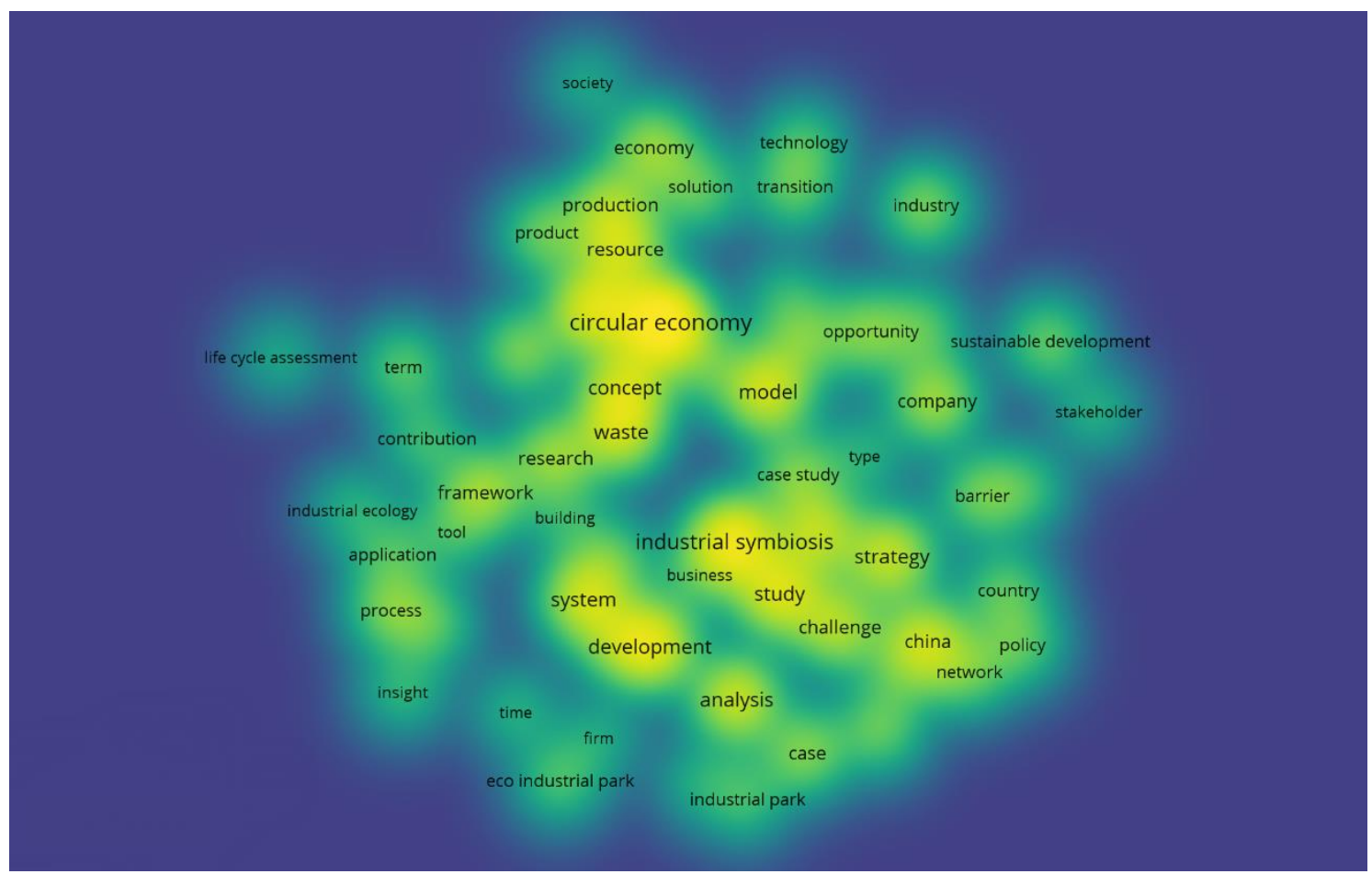

Figure 3 - Density analysis

As can be seen from Figure 3, no subtopics with the maximum density are contacted. Thus, we can say that, in general, the subject under study is still not much explored and more studies are needed.

It is verified that with the with a medium density the key terms of research used in this investigation (industrial symbiosis and circular economy) appear. However, we can verify that there is already some research in models developed for the subject (Bocken et al., 2016; Urbinati et al., 2017). The challenges, opportunities development, and analysis in the theme are also subtopics that arise with an average density (Clark et al., 2016; Geng \& Doberstein, 2008; Geng et al., 2012; Urbinati et al., 2017). The resources necessary for the production of (Gregson et al., 2015; Yang \& Feng, 2008), and IS business and strategy (Aid et al., 2017; Álvarez \& Ruiz-Puente, 2017).

However, there are many sub-themes with a minimum density. These sub-themes should serve as a basis for further research: What is the role of the industrial eco-park in IS? What policies should be followed to successfully implement the CE? What are the barriers to implementing a CE? How can the impact of EC implementation in regions be measured? How to measure the performance of an IS? How to make CE sustainable? How to evaluate the life cycle of IS products? What impact does the
CE have on society? How can technology contribute to the development of IS? What role do stakeholders play in IS implementation?

\section{Final Remarks}

The present research aimed to provide a comprehensive view of academic studies that simultaneously address CE and IS and their sustainability. It was intended to identify gaps in the literature and provide possible directions for future lines of research in the subject. In this context, the following research questions were established: Who are the protagonists, considering the source of the publications as well as the authors? Which methodologies and types of research are most used? What is the geographic focus of literature? What are the streams of future research lines?

It was found that in the first phase, the academicians focused their proposed models to implement and develop the CE and the IS. They also focused on the factors, processes, dynamics, and policies that result from the CE and IS with the objective of the sustainability of the regions and their companies. In a second phase, scholars studied the transition from a linear economy to a circular economy, product design and business modeling strategies for companies, problems in their 
implementation, and forms of cooperation to create synergies between companies.

It was found that the articles published in the subject under study, in the first stage the existence of many conceptual articles and some qualitative. In a second phase, the studies are in general qualitative. Thus, it can be stated that to complement the results found in the published articles, it is recommended that studies be done using a quantitative methodology to generalize the results.

For countries that contribute most to the scientific productivity in the subject in question, what stands out most is China with 15 articles and 492 citations, the Netherlands with 10 published articles and 341 citations and England also with 10 articles, but with 244 quotes. China is the country that has given more importance to the study on the subject, besides being the country that stands out the most in the implementation of CE and IS in their regions. It can be said that it is one of the pioneers and most advanced countries in the implementation of CE and IS. It was also verified that the most influential author in the subject is Geng, Y with 354 citations in 8 published articles.

Regarding the magazines that publish more in the subject, the "Journal of Cleaner Production" is the one that stands out more. Second is the journal "Resources Conservation and Recycling" and thirdly the "Journal of Industrial Ecology".

It was identified which clusters where the academics have focused more on their investigation. Cluster 1, with 17 articles studies the "circular economy: approaches and tools". Cluster 2, with 11 articles, addresses the "industrial symbiosis dynamics". Cluster 3, with 8 articles, studies the "circular economy: strategies and performance". Finally, cluster 4, with 6 articles, develops "the efficiency of resources in symbiosis industry".

Further research questions have been developed that should serve as a basis for further research: What is the role of the industrial eco-park in IS? What policies should be followed to successfully implement the EC? What are the barriers to implementing an EC? How can the impact of EC implementation in regions be measured? How to measure the performance of an IS? How to make EC sustainable? How to evaluate the life cycle of IS products? What impact does the EC have on society? How can technology contribute to IS development? What role do stakeholders play in IS implementation?

In terms of the limitations of the study, as far as the methodology is concerned, it is possible not to exclude publications that are not articles, thus using more raw materials. Other databases and other software may be used to perform the analysis. The selection of key search terms used may have excluded some studies that were relevant to the present investigation.
With this work, some future lines of research are suggested. A meta-analysis study is also a possibility for future research.

\section{References}

[1] Abreu, M. C. S., \& Ceglia, D. (2018). On the implementation of a circular economy: The role of institutional capacity-building through industrial symbiosis. Resources, Conservation and Recycling, 138, 99-109.

[2] Afshari, H., Farel, R., \& Peng, Q. (2018). Challenges of value creation in Eco-Industrial Parks (EIPs): A stakeholder perspective for optimizing energy exchanges. Resources, Conservation and Recycling, 139, 315-325.

[3] Aguiñaga, E., Henriques, I., Scheel, C., \& Scheel, A. (2018). Building resilience: A self-sustainable community approach to the triple bottom line. Journal of Cleaner Production, 173, 186-196.

[4] Aid, G., Eklund, M., Anderberg, S., \& Baas, L. (2017). Expanding roles for the Swedish waste management sector in inter-organizational resource management. Resources, Conservation and Recycling, 124, 85-97.

[5] Albort-Morant, G., \& Ribeiro-Soriano, D. (2016). A bibliometric analysis of international impact of business incubators. Journal of Business Research, 69(5), 1775-1779.

[6] Alvarez, R., \& Ruiz-Puente, C. (2017). Development of the Tool SymbioSyS to Support the Transition Towards a Circular Economy Based on Industrial Symbiosis Strategies. Waste and Biomass Valorization, 8(5), 1521-1530.

[7] Álvarez, R., \& Ruiz-Puente, C. (2017). Development of the Tool SymbioSyS to Support the Transition Towards a Circular Economy Based on Industrial Symbiosis Strategies. Waste and Biomass Valorization, 8(5), 1521-1530.

[8] Angelis, R., Howard, M., \& Miemczyk, J. (2018). Supply chain management and the circular economy: towards the circular supply chain. Production Planning \& Control, 29(6), 425-437.

[9] Ayres, R. U., \& Ayres, L. (2002). A handbook of industrial ecology. Cheltenham, UK: Edward Elgar Publishing.

[10] Bellantuono, N., Carbonara, N., \& Pontrandolfo, P. (2017). The organization of eco-industrial parks and their sustainable practices. Journal of Cleaner Production, 161, 362-375.

[11] Besio, C., \& Pronzini, A. (2014). Morality, Ethics, and Values Outside and Inside Organizations: An Example of the Discourse on Climate Change. Journal of Business Ethics, 119(3), 287300.

[12] Blomsma, F. (2018). Collective 'action recipes' in a circular economy - On waste and resource management frameworks and their role in collective change. Journal of Cleaner Production, 199, 969-982. 
[13] Bocken, N. M. P., de Pauw, I., Bakker, C., \& van der Grinten, B. (2016). Product design and business model strategies for a circular economy. Journal of Industrial and Production Engineering, 33(5), 308-320.

[14] Boix, M., Montastruc, L., Azzaro-Pantel, C., \& Domenech, S. (2015). Optimization methods applied to the design of eco-industrial parks: a literature review. Journal of Cleaner Production, 87, 303-317.

[15] Boons, F., Spekkink, W., \& Mouzakitis, Y. (2011). The dynamics of industrial symbiosis: a proposal for a conceptual framework based upon a comprehensive literature review. Journal of Cleaner Production, 19(9-10), 905911.

[16] Boulding, K. E. (1966). The economics of coming Spaceship Earth. In H. Jarrett (Ed.), Environmental quality in a growing economy (pp. 3-14). Baltimore, MD: John Hopkins University Press.

[17] Bouyssou, D., \& Marchant, T. (2011). Ranking Scientists and Departments in a Consistent Manner. Journal of the American Society for Information Science and Technology, 62(9), 1761-1769.

[18] Ceglia, D., Abreu, M. C. S., \& Silva Filho, J. C. L. (2017). Critical elements for eco-retrofitting a conventional industrial park: Social barriers to be overcome. J Environ Manage, 187, 375-383.

[19] Chertow, M., \& Ehrenfeld, J. (2012). Organizing self-organizing systems: Toward a theory of industrial symbiosis. Journal of Industrial Ecology, 16(1), 13-27.

[20] Chertow, M. R. (2007). "Uncovering” industrial symbiosis. Journal of Industrial Ecology, 11(1), 11-30.

[21] Clark, J. H., Farmer, T. J., Herrero-Davila, L., \& Sherwood, J. (2016). Circular economy design considerations for research and process development in the chemical sciences. Green Chemistry, 18(14), 3914-3934.

[22] Cooper, H., \& Valentine, J. C. (2008). Research synthesis and meta-analysis. In L. Bickman \& D. J. Rog (Eds.), Handbook of applied social research methods (pp. 315-342). Thousand Oaks: Sage Publications.

[23] Crang, M., Fuller, S., \& Holmes, H. (2015). Interrogating the circular economy: the moral economy of resource recovery in the EU AU Gregson, Nicky. Economy and Society, 44(2), 218-243.

[24] Du, Z. R. (2016). Planning Framework of the Circular Economy Eco-City. Open House International, 41(3), 71-75.

[25] Duque Oliva, E. J., Cervera Taulet, A., \& Rodríguez Romero, C. (2006). A bibliometric analysis of models measuring the concept of perceived quality inproviding internet service. Innovar, 16(28), 223-243.
[26] Eck, N., \& Waltman, L. (2009). Software survey: VOSviewer, a computer program for bibliometric mapping. Scientometrics, 84(2), 523-538.

[27] Ferreira, P. G., Silva, F. C., \& Ferreira, V. F. (2017). The Importance of Chemistry for the Circular Economy. Revista Virtual De Quimica, $9(1), 452-473$

[28] Fraccascia, L., \& Yazan, D. M. (2018). The role of online information-sharing platforms on the performance of industrial symbiosis networks. Resources Conservation and Recycling, 136, 473485.

[29] Franceschini, S., Faria, L. G. D., \& Jurowetzki, R. (2016). Unveiling scientific communities about sustainability and innovation. A bibliometric journey around sustainable terms. Journal of Cleaner Production, 127, 72-83.

[30] Franklin-Johnson, E., Figge, F., \& Canning, L. (2016). Resource duration as a managerial indicator for Circular Economy performance. Journal of Cleaner Production, 133, 589-598.

[31] Frone, D. F., \& Frone, S. (2017a). Circular Economy in Romania: An Industrial Synergy in the Agri-Food Sector. Scientific Papers-Series Management Economic Engineering in Agriculture and Rural Development, 17(2), 103109.

[32] Frone, D. F., \& Frone, S. (2017b). Eco-Innovation Park Promoting the Green Economy in Romania. Scientific Papers-Series Management Economic Engineering in Agriculture and Rural Development, 17(2), 111-119.

[33] Geng, Y., \& Doberstein, B. (2008). Developing the circular economy in China: Challenges and opportunities for achieving 'leapfrog development'. International Journal of Sustainable Development and World Ecology, 15(3), 231-239.

[34] Geng, Y., Fu, J., Sarkis, J., \& Xue, B. (2012). Towards a national circular economy indicator system in China: an evaluation and critical analysis. Journal of Cleaner Production, 23(1), 216-224.

[35] Geng, Y., Mitchell, B., \& Zhu, Q. H. (2009). Teaching Industrial Ecology at Dalian University of Technology. Journal of Industrial Ecology, 13(6), 978-989.

[36] Geng, Y., Zhu, Q., Doberstein, B., \& Fujita, T. (2009). Implementing China's circular economy concept at the regional level: A review of progress in Dalian, China. Waste Management, 29(2), 996-1002.

[37] George, D. A. R., Lin, B. C. A., \& Chen, Y. M. (2015). A circular economy model of economic growth. Environmental Modelling \& Software, $73,60-63$.

[38] Gregson, N., Crang, M., Fuller, S., \& Holmes, H. (2015). Interrogating the circular economy: the 
moral economy of resource recovery in the EU. Economy and Society, 44(2), 218-243.

[39] Griffiths, P., \& Cayzer, S. (2016). Design of indicators for measuring product performance in the circular economy Sustainable Design and Manufacturing 2016 (pp. 307-321): Springer.

[40] Guo, B., Geng, Y., Sterr, T., Dong, L., \& Liu, Y. (2016). Evaluation of promoting industrial symbiosis in a chemical industrial park: A case of Midong. Journal of Cleaner Production, 135, 995-1008.

[41] Guo, B., Geng, Y., Sterr, T., Zhu, Q., \& Liu, Y. (2017). Investigating public awareness on circular economy in western China: A case of Urumqi Midong. Journal of Cleaner Production, 142, 2177-2186.

[42] Hara, K., Yabar, H., Uwasu, M., \& Zhang, H. (2011). Energy intensity trends and scenarios for China's industrial sectors: a regional case study. Sustainability Science, 6(2), 123-134.

[43] Herczeg, G., Akkerman, R., \& Hauschild, M. Z. (2018). Supply chain collaboration in industrial symbiosis networks. Journal of Cleaner Production, 171, 1058-1067.

[44] Hill, J. E. (2014). The circular economy: from waste to resource stewardship, part I. Paper presented at the Institution of Civil EngineersWaste and Resource Management.

[45] Jawahir, I. S., \& Bradley, R. (2016). Technological Elements of Circular Economy and the Principles of 6R-Based Closed-loop Material Flow in Sustainable Manufacturing. Paper presented at the 13th Global Conference on Sustainable Manufacturing, GCSM 2015.

[46] Jesus, A., \& Mendonça, S. (2018). Lost in Transition? Drivers and Barriers in the Ecoinnovation Road to the Circular Economy. Ecological Economics, 145, 75-89.

[47] Jiao, W., \& Boons, F. (2017). Policy durability of Circular Economy in China: A process analysis of policy translation. Resources, Conservation and Recycling, 117, 12-24.

[48] Keupp, M. M., Palmié, M., \& Gassmann, 0. (2012). The strategic management of innovation: A systematic review and paths for future research. International Journal of Management Reviews, 14(4), 367-390.

[49] Kirchherr, J., Reike, D., \& Hekkert, M. (2017). Conceptualizing the circular economy: An analysis of 114 definitions. Resources Conservation and Recycling, 127, 221-232.

[50] Kuznetsova, E., Zio, E., \& Farel, R. (2016). A methodological framework for Eco-Industrial Park design and optimization. Journal of Cleaner Production, 126, 308-324.

[51] Leydesdorff, L. (2005). Similarity measures, author cocitation analysis, and information theory. Journal of the American society for Information Science and Technology, 56(7), 769772.
[52] Li, H., Dong, L., \& Ren, J. (2015). Industrial symbiosis as a countermeasure for resource dependent city: a case study of Guiyang, China. Journal of Cleaner Production, 107, 252-266.

[53] Liu, Z., Adams, M., Cote, R. P., Geng, Y., Chen, Q., Liu, W., . . . Yu, X. (2017). Comprehensive development of industrial symbiosis for the response of greenhouse gases emission mitigation: Challenges and opportunities in China. Energy Policy, 102, 88-95.

[54] Liu, Z., Adams, M., Cote, R. P., Geng, Y., \& Li, Y. (2018). Comparative study on the pathways of industrial parks towards sustainable development between China and Canada. Resources, Conservation and Recycling, 128, 417425.

[55] Liu, Z., Yin, Y., Liu, W., \& Dunford, M. (2015). Visualizing the intellectual structure and evolution of innovation systems research: a bibliometric analysis. Scientometrics, 103(1), 135-158.

[56] Loiseau, E., Saikku, L., Antikainen, R., Droste, N., Hansjürgens, B., Pitkänen, K., . . . Thomsen, M. (2016). Green economy and related concepts: An overview. Journal of Cleaner Production, 139, 361-371.

[57] Lopes, J., Ferreira, J. J., \& Farinha, L. (2018). Innovation strategies for smart specialisation (RIS3): Past, present and future research. Growth and Change.

[58] Manara, P., \& Zabaniotou, A. (2016). Covalorization of Crude Glycerol Waste Streams with Conventional and/or Renewable Fuels for Power Generation and Industrial Symbiosis Perspectives. Waste and Biomass Valorization, 7(1), 135-150.

[59] Mathews, J. A., \& Tan, H. (2011). Progress Toward a Circular Economy in China. Journal of Industrial Ecology, 15(3), 435-457.

[60] Mathews, J. A., Tang, Y., \& Tan, H. (2011). China's move to a Circular Economy as a development strategy. Asian Business \& Management, 10(4), 463-484.

[61] Mattila, T., Lehtoranta, S., Sokka, L., Melanen, M., \& Nissinen, A. (2012). Methodological Aspects of Applying Life Cycle Assessment to Industrial Symbioses. Journal of Industrial Ecology, 16(1), 51-60.

[62] McDonough, W., \& Braungart, M. (2010). Cradle to cradle: Remaking the way we make things. New York: North point press.

[63] McDowall, W., Geng, Y., Huang, B. J., Bartekova, E., Bleischwitz, R., Turkeli, S., . . . Domenech, T. (2017). Circular Economy Policies in China and Europe. Journal of Industrial Ecology, 21(3), 651-661.

[64] Merli, R., Preziosi, M., \& Acampora, A. (2018). How do scholars approach the circular economy? A systematic literature review. Journal of Cleaner Production, 178, 703-722. 
[65] Milios, L. (2018). Advancing to a Circular Economy: three essential ingredients for a comprehensive policy mix. Sustainability Science, 13(3), 861-878.

[66] Mohammed, F., Biswas, W. K., Yao, H. M., \& Tade, M. (2018). Sustainability assessment of symbiotic processes for the reuse of phosphogypsum. Journal of Cleaner Production, 188, 497-507.

[67] Mulrow, J. S., Derrible, S., Ashton, W. S., \& Chopra, S. S. (2017). Industrial Symbiosis at the Facility Scale. Journal of Industrial Ecology, 21(3), 559-571.

[68] Murray, A., Skene, K., \& Haynes, K. (2017). The Circular Economy: An Interdisciplinary Exploration of the Concept and Application in a Global Context. Journal of Business Ethics, 140(3), 369-380.

[69] Nasiri, M., Rantala, T., Saunila, M., Ukko, J., \& Rantanen, H. (2018). Transition towards Sustainable Solutions: Product, Service, Technology, and Business Model. Sustainability, $10(2), 358$.

[70] Ness, D. A., \& Xing, K. (2017). Toward a Resource-Efficient Built Environment: A Literature Review and Conceptual Model. Journal of Industrial Ecology, 21(3), 572-592.

[71] Ormazabal, M., Prieto-Sandoval, V., Puga-Leal, R., \& Jaca, C. (2018). Circular Economy in Spanish SMEs: Challenges and opportunities. Journal of Cleaner Production, 185, 157-167.

[72] Pan, H., Zhang, X., Wang, Y., Qi, Y., Wu, J., Lin, L., . .. Zhang, Y. (2016). Emergy evaluation of an industrial park in Sichuan Province, China: A modified emergy approach and its application. Journal of Cleaner Production, 135, 105-118.

[73] Patricio, J., Axelsson, L., Biome, S., \& Rosado, L. (2018). Enabling industrial symbiosis collaborations between SMEs from a regional perspective. Journal of Cleaner Production, 202, 1120-1130.

[74] Patricio, J., Axelsson, L., Blomé, S., \& Rosado, L. (2018). Enabling industrial symbiosis collaborations between SMEs from a regional perspective. Journal of Cleaner Production, 202, 1120-1130.

[75] Peck, D., Kandachar, P., \& Tempelman, E. (2015). Critical materials from a product design perspective. Materials \& Design, 65, 147-159.

[76] Pigosso, D. C. A., Schmiegelow, A., \& Andersen, M. M. (2018). Measuring the Readiness of SMEs for Eco-Innovation and Industrial Symbiosis: Development of a Screening Tool. Sustainability, 10(8), 2861.

[77] Prendeville, S., Cherim, E., \& Bocken, N. (2018). Circular Cities: Mapping Six Cities in Transition. Environmental Innovation and Societal Transitions, 26, 171-194.

[78] Prieto-Sandoval, V., Jaca, C., \& Ormazabal, M. (2018). Towards a consensus on the circular economy. Journal of Cleaner Production, 179, 605-615.

[79] Prieto-Sandoval, V., Ormazabal, M., Jaca, C., \& Viles, E. (2018). Key elements in assessing circular economy implementation in small and medium-sized enterprises. Business Strategy and the Environment, 27(8), 1525-1534.

[80] Prieto-Sandoval, V., Ormazabal, M., Jaca, C., \& Viles, E. (2018). Key elements in assessing circular economy implementation in small and medium-sized enterprises. Business Strategy and the Environment, 27(8), 1525-1534.

[81] Pritchard, A. (1969). Statistical Bibliography or Bibliometrics. Journal of documentation, 25(4), 348-+.

[82] Prosman, E. J., Wæhrens, B. V., \& Liotta, G. (2017). Closing Global Material Loops: Initial Insights into Firm-Level Challenges. Journal of Industrial Ecology, 21(3), 641-650.

[83] Renzulli, P. A., Notarnicola, B., Tassielli, G., Arcese, G., \& Di Capua, R. (2016). Life Cycle Assessment of Steel Produced in an Italian Integrated Steel Mill. Sustainability, 8(8), 719.

[84] Saavedra, Y. M. B., Iritani, D. R., Pavan, A. L. R., \& Ometto, A. R. (2018). Theoretical contribution of industrial ecology to circular economy. Journal of Cleaner Production, 170, 1514-1522.

[85] Sappinen, T., Orkas, J., \& Kronqvist, T. (2018). Thermal Reclamation of Foundry Sands Using Repurposed Sand Dryer Equipment. Archives of Foundry Engineering, 18(4), 99-102.

[86] Schneider, A. (2015). Reflexivity in sustainability accounting and management: Transcending the economic focus of corporate sustainability. Journal of Business Ethics, 127(3), 525-536.

[87] Sposato, P., Preka, R., Cappellaro, F., \& Cutaia, L. (2017). Sharing Economy and Circular Economy. How Technology and Collaborative Consumption Innovations Boost Closing the Loop Strategies. Environmental Engineering and Management Journal, 16(8), 1797-1806.

[88] Strazza, C., Magrassi, F., Gallo, M., \& Del Borghi, A. (2015). Life Cycle Assessment from food to food: A case study of circular economy from cruise ships to aquaculture. Sustainable Production and Consumption, 2, 40-51.

[89] Sun, L., Li, H., Dong, L., Fang, K., Ren, J., Geng, Y., . . . Liu, Z. (2017). Eco-benefits assessment on urban industrial symbiosis based on material flows analysis and emergy evaluation approach: A case of Liuzhou city, China. Resources, Conservation and Recycling, 119, 78-88.

[90] Urbinati, A., Chiaroni, D., \& Chiesa, V. (2017). Towards a new taxonomy of circular economy business models. Journal of Cleaner Production, 168, 487-498.

[91] Van Beers, D., Bossilkov, A., Corder, G., \& Van Berkel, R. (2007). Industrial symbiosis in the Australian minerals industry: the cases of 
Kwinana and Gladstone. Journal of Industrial Ecology, 11(1), 55-72.

[92] Velenturf, A. P. M., Purnell, P., Tregent, M., Ferguson, J., \& Holmes, A. (2018). Co-Producing a Vision and Approach for the Transition towards a Circular Economy: Perspectives from Government Partners. Sustainability, 10(5), 1401.

[93] Wang, H., Xu, X., \& Zhu, G. (2015). Landscape Changes and a Salt Production Sustainable Approach in the State of Salt Pan Area Decreasing on the Coast of Tianjin, China. Sustainability, 7(8), 10078.

[94] Wang, Q., Deutz, P., \& Chen, Y. (2017). Building institutional capacity for industrial symbiosis development: A case study of an industrial symbiosis coordination network in China. Journal of Cleaner Production, 142, 1571-1582.

[95] Winans, K., Kendall, A., \& Deng, H. (2017). The history and current applications of the circular economy concept. Renewable \& Sustainable Energy Reviews, 68, 825-833.
[96] Wu, H. Q., Shi, Y., Xia, Q., \& Zhu, W. D. (2014). Effectiveness of the policy of circular economy in China: A DEA-based analysis for the period of 11th five-year-plan. Resources Conservation and Recycling, 83, 163-175.

[97] Xue, B., Chen, X.-p., Geng, Y., Guo, X.-j., Lu, C.-p., Zhang, Z.-l., \& Lu, C.-y. (2010). Survey of officials' awareness on circular economy development in China: based on municipal and county level. Resources, Conservation and Recycling, 54(12), 1296-1302.

[98] Yang, S. L., \& Feng, N. P. (2008). Case study of industrial symbiosis: Nanning Sugar Co., Ltd. in China. Resources Conservation and Recycling, 52(5), 813-820.

[99] Yu, C., de Jong, M., \& Dijkema, G. P. J. (2014). Process analysis of eco-industrial park development - the case of Tianjin, China. Journal of Cleaner Production, 64, 464-477. 